\section{New Foreign Members of the Linnean Society}

THE four recently elected foreign members of the Linnean Society are all botanists. Dr. A. F. Blakeslee, assistant director in the Department of Genetics at the Carnegie Institution of Washington, is not only an outstanding geneticist but was also the discoverer of the phenomenon of heterothallism in the Mucorineæ, which has had a most profound influence both on the study of fungi and on theories of sex. Prof. P. A. Dangeard, until lately professor of botany at the Sorbonne, is known chiefly as a mycologist and cytologist though he has covered a very wide field in botanical research: he has been responsible for Le Botaniste since 1889, contributing the whole of many of the volumes. Prof. G. Senn, director of the Botanical Institute at Basle, is a botanist of many-sided activities. At first mainly interested in algal flagellates, he turned his attention to the physiology of the plant cell, studying particularly the chromatophore. More recently he has written a valuable treatise on the botany of Theophrastus. He has also worked on alpine plants. Prof. C. Raunkiaer, formerly professor of botany at Copenhagen, has considerably influenced ecological thought by his work on growth forms. He has been chiefly interested in phytogeography, morphology, taxonomy and statistical methods. His papers have recently been translated into English under the title "The Life Forms of Plants and Statistical Plant Geography".

\section{Dr. Herbert Smith}

The Principal Trustees of the British Museum have appointed Dr. George Frederick Herbert Smith to be keeper of mineralogy in the British Museum (Natural History), in succession to Dr. L. J. Spencer, who retires on July 7 next. Dr. Herbert Smith was born in 1872. He was educated at Winchester, and at New College, Oxford, where he held a Winchester scholarship. He took a first in Mathematical Moderations (1892), Final School of Mathematics (1895) and Natural Science School, Physics (1896). He entered the Museum as an assistant in the Department of Mineralogy in 1897, and soon became recognised as an authority on mineralogy and crystallography, and wrote numerous papers on these subjects. His book on gem-stones has for many years been used as the standard textbook in the jewellery trade. $\mathrm{He}$ invented the three-circle goniometer, and a handrefractometer for the determination of gem-stones. Dr. Herbert Smith's interest in general civil service problems led to his appointment in 1921 to the post of secretary of the Museum, which he has since held. $\mathrm{He}$ is honorary secretary of the Society for the Promotion of Nature Reserves, and chairman of the Wild Plant Conservation Board.

\section{Franklin Institute Medals Awards}

SCIEnCE SERvice of Washington, D.C., states that the Franklin Institute, Philadelphia, has recently awarded Franklin Medals to Prof. Albert Einstein for his researches on relativity and the photo-electric effect, and to Sir Ambrose Fleming for his work on the thermionic valve. A certificate of merit has been awarded to G. S. Kelley, of New York, for reducing rock dust hazard. The following medal awards have also been made for the work indicated: Edward Longstreth Medals to Edmund Bruce of the Bell Telephone Laboratories (short wave radio antennæ) ; Howard D. Colman and B. A. Petersen of Rockford (an automatic spooler); P. Davey of New York (a portable balancing device); and K. B. MeEachron of the General Electric Co., Pittsfield (for developing the material thyrite): John Price Wetherill Medals to Dr. F. F. Lucas of the Bell Telephone Laboratories (photomicroscopy); R. E. Naumburg of New York (an unusual mechanical apparatus); W. H. Shortt and F. Hope-Jones (precision clocks); Dr. J. E. Shrader of Drexel Institute, Philadelphia (a vibrationmeasuring instrument); Dr. L. B. Tuckerman of the National Bureau of Standards (an optical strain gauge); H. E. Warren of Ashland, Mass. (the telechron used in electric clocks): Walton Clark Gas Medal to F. J. West of Manchester (work in the gas industry): Louis Edward Levy Medal to Dr. H. L. Hazen of the Massachusetts Institute of Technology (mechanical robots or servo-mechanisms).

\section{The Quetta Earthquake of May 3I}

WrrHIN little more than sixteen months, the Indian Empire has been visited by another great destructive earthquake. On May 31, at about 2.45 a.m. (probably about 9.15 p.m. on May 30 , G.M.T.), the cities of Quetta, Mastung and Kalat were almost entirely razed to the ground. In Quetta alone, the loss of life is estimated at more than 20,000. The region is one that has frequently been disturbed by destructive earthquakes. The valuable report by $\mathrm{Mr}$. W. D. West on those of August 25 and 27, 1931, has recently been noticed in Nature (April 27, p. 661). The earlier shock had its centre near Sharigh, which lies 39 miles east of Quetta; the later and stronger near Mach, 26 miles south-east of the same city. In the recent earthquake, the epicentral area-if we may take it as lying along the Quetta-Mastung-Kalat line-is roughly parallel to the zone joining Sharigh to the main part of the Mach area, and about 50 miles to the west. It is also parallel to the main structural lines of the country, and especially to the great boundary fault, 45 miles to the west, that runs along the west side of the Khojak Range for a distance of at least 120 miles. It was to a nearly horizontal shift of about $2 \frac{1}{4} \mathrm{ft}$. along this fault that the severe earthquake of December 20, 1892, was due.

\section{Revision of Ordnance Survey Maps}

WE are glad to note that the Minister of Agriculture has appointed a committee, under the chairmanship of Mr. J. C. C. Davidson, Chancellor of the Duchy of Lancaster, to consider the measures necessary to accelerate the revision of the Ordnance Survey maps. The maps in question are the large-scale plans, that is, the 25-in., the 6-in. and, in some cases, even those on larger scales, but chiefly those 